\title{
Good Intentions, Cheap Food and Counterpart Funds
}

\author{
CLIFTON B. LUTTRELL
}

I $N$ the not-so-distant past, the United States agricultural price-support programs provided an incentive for the production of bountiful harvests and huge amounts of surplus foods. In response, the U.S. govemment developed a variety of programs to reduce these surpluses by selling them abroad at sharply reduced prices to less developed countries. The sales of "cheap" food for nonconvertible currencies and the ways in which the receipts were used in the various countries have generated considerable discussion and controversy among economists.

Although the sales of food for these currencies were initiated in the early 1950 s and had been phased out by the early $1970 \mathrm{~s}$, a brief review of the impact of this program is timely for at least two reasons: (1) payments generated by it, called comterpart funds, still exist and have had important consequences long after the program itself has been phased out; and (2) it appears that the United States, once again, is facing ever-increasing farm surpluses. Before decisions are nade to "reduce" these surpluses, it would be useful to assess the impact of the prior programs on both the United States and the beneficiaries. This article does not attempt an exhaustive survey of the prior programs. Instead, it focuses on the arguments used to establish the comterpart funds program and its impacts.

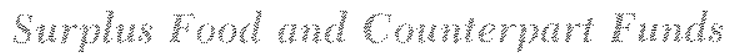

The Agricultural Trade Development and Assistance Act of 1954 (P.L. 480), designed to increase exports of U.S. "surplus" farm products to less developed countries (LDCs), led to the creation of counterpart funds. These funds are nonconvertible currencies of foreign nations credited to the United States in payment for shipments of the surplus agricultural commodities. The uses that can be made of the acomnts are highly restricted - largely limited to U.S. embassy expenses, market development, common defense and economic development in the respective LDCs.

\section{Sownter of the ateonats}

Under P.L. 480, the United States sells surplus farm commodities to friendly LDCs in exchange for foreign currencies. In these negotiations authorized under the act, the President is required to ensure, insofar as practicable, that such sales do not replace the normal sales of the same products by the United States or other friendly nations. 'This requirement, in effect, limited P.L. 480 shipments to nations that had relatively small amounts of foreign exchange (gold or convertible currency).

With minor exceptions, foreign currencies obtained from the export of these farm commodity surpluses initially were deposited in U.S. accounts in the central banks of the importing countries and could, with few exceptions, be spent only in these countries. As the currencies were used they were withdrawn from the central bank accounts. The Commodity Credit Corporation (CCC), an agency of the U.S. Department of Agriculture, is responsible for financing the sale and export of the commodities. Any U.S. agency that funds its foreign activities by drawing on this account must remburse the $\mathrm{COC}$.

The Food for Peace Act of 1966 altered the arrangements under P.L. 480 by requiring that most food shipments would be sold for dollars, instead of foreign currencies, with the transition to be completed by the end of $19711^{2}$ As a result of this policy change, sales of farm products for foreign currencies, which reached a peak of $\$ 1.7$ billon in 1963, were phased ont in the early $1970 \mathrm{~s} .{ }^{3}$ Because a sizable portion of the $\$ 18$ bil-

The author wishes to arknowedge the helpful comments recence on this paper from T. W. Schults, of the Unicersity of Chicago.

"Agricultural Trate Development and Assistunce Act of 1954," V.S. Code Congressional and Administratice Neses, Vol. 1 , West Publishing Co, and Edward Thompson $C_{0}, 1954$ ) pl. $506-12$.

"2"Fod for Peace Act of 1966." U.S. Code Coneressional and Administrative Nows, Fol I West Publishing Co. 1966) pp. 1761-76.

"U.S. Department of Agriculure, Food for Peace: 1980 Ammal Repert on Public Law 480 , U.S. Government printing office. 1981 table 6 . 
Table 1

Uses of Foreign Currency Provided in Title I, P.L. 480

Shipments, July 1, 1954, through September 30, 1980 (amounts in millions of dollars)

\begin{tabular}{|c|c|c|c|c|}
\hline & \multicolumn{2}{|c|}{ Allounnes } & \multicolumn{2}{|c|}{ ndat } \\
\hline & Amount & $\begin{array}{l}\text { Percent } \\
\text { distribution }\end{array}$ & Amount & $\begin{array}{l}\text { Percent } \\
\text { distribution }\end{array}$ \\
\hline Common defense & $\$ 2187$ & $14 \%$ & $\$$ & $0 \%$ \\
\hline Loans bo prvate enteptse & 413 & 3 & 254 & 6 \\
\hline Grants for econonic development & 1838 & 11 & 696 & 17 \\
\hline Loans to foregn governments & 5,157 & 32 & 2,494 & 61 \\
\hline Population growth programs & 86 & ० & 32 & 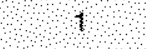 \\
\hline Control of rodens insects etc & 2 & 0 & 2 & 0 \\
\hline Loans and grants & 2,204 & 14 & & \\
\hline $0 S$ uses & 4,103 & 26 & 599 & 15 \\
\hline IOAL & $\$ 15,968$ & $100 \%$ & 84,077 & $100 \%$ \\
\hline
\end{tabular}

1954 to 1973 only,

SOURCES, U.S Departinent of Agniculture, food for Peace, 1980 Annual Repor on Public Law 480 . table 14, and 1973 Annual Feport on Piblic Law 480 table 13

lion in counterpart funds obtained during the 1955-74 period was not spent directly, but loaned to both government and private enterprises in the food-importing nations, it continued to be made available through principal and interest payments on these loans. The counterpart fund balances held by the U.S. Treasury and other exectitive agencies of the government totaled $\$ 1.1$ billion on September 30, $1980 .^{*}$

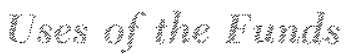

The uses of the foreign currencies provided by the P.L. 480 agreements since 1954 are shown in table 1 . Grants for economic development and loans to foreign govermments, also largely for economic development, accounted for 44 percent of the total. Common defense and loans and grants to others accounted for 14 percent each, and U.S. uses accounted for 26 percent.

Authorized U.S. uses for the funds included developing new markets for U.S. farm commodities, scientific, cultural and educational programs, sales of such currencies to U.S organizations and citizens, and paying U, S. obligations abroad (table 2). The National Park Service has used the currencies to develop and manage programs for the conservation of endangered

\footnotetext{
${ }^{4}$ Annual Report of the Secretary of the Treasury on the State of the Finances, Statistical Appendix, (GPO, 1981), Fiscal Year 1980, p. 431.
}

or threatened species. The Environmental Protection Agency uses the funds to support research in a number of countries ostensibly for developing standards and regulations applicable to the United States. ${ }^{5}$

U.S. officials concede that many of these overseas programs exist solely because the foreign currencies are available. For example, the U.S. Department of Labor uses some of the Indian currency for yearly meetings of government officials and labor attachés from various embassies. Robert Greenberger of the Wall Street Journal quoted one official who attended the 1982 meeting in New Delhi as saying, "The ammual gatherings are important because things are moving fast in the international labor world." Despite this hectic pace, the U.S. Department of Labor issued no written report "because we didn't think it was needed . . . besides if we had [written one] it would have been classified." Furthermore, because inflation in the various countries reduces the value of the funds each succeeding year, there is additional incentive to accelerate the rate of spending of these funds, regardless of the use derived. ${ }^{6}$

\footnotetext{
U.S, Department of Agriculture, Food for Peace: 1980 Annual Report on Public Law 480

"Robert S. Greenberger, "It May Surprise You But Uncle Sam Has Too Much Money," The Wall Street Jownal, July 21, 1982.
} 
Table 2

\section{U.S. Uses of Title I, P.L. 480 Foreign Currencies Through} September 30, 1979 (amounts in millions of dollars)

\begin{tabular}{|c|c|c|}
\hline Agency and P Upose & 4roun & Pistribution \\
\hline \multicolumn{3}{|l|}{ Agericy lor inernational Development } \\
\hline Acquistions of stes, butings and grounds. & 26. & $0.0 \%$ \\
\hline 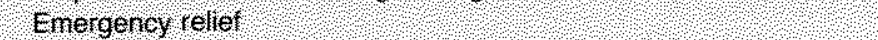 & 11.6 & 02 \\
\hline Purchases of goods and servees tor other friendy countres: & 1705 & 43 \\
\hline Agreature $\checkmark$ ২ & & \\
\hline Trade lairs, narket development and scientitic activities & 3016 & 8.1 \\
\hline 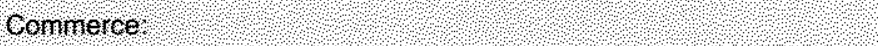 & & \\
\hline Trade fairs market development and sclentife activites & 198 & 08 \\
\hline Defense: ४ & & \\
\hline Mitary tanily housitg & 92.3 & 23 \\
\hline Oher prograns $४$ ४ & 405 & 10 \\
\hline Energy & 00 & 00 \\
\hline Environmental protection & 265 & 0,6 \\
\hline tealt, Edlocation and Weltare: & & \\
\hline Inernational educationa, culural excharige and scientific actultes & 1885 & 46 \\
\hline Inerior: ২৬৭ ২৭: & & \\
\hline Scientific actuities & 54 & 0.1 \\
\hline International Communication Agency & & \\
\hline 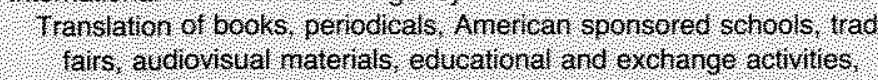 & & \\
\hline Preservation of Nubien nonuments and ennergency relef grants & $47 \%$ & 102 \\
\hline Labor & & \\
\hline Interlational labor meetings & 0.2 & 00 \\
\hline Library of Congress? & & \\
\hline Evaluating forelgn publications & 36.8 & 09 \\
\hline National Sclence Foundation & & \\
\hline Scentife activites & 481 & 12 \\
\hline $\begin{array}{l}\text { Snithsonian instituion: } \\
\text { Scientife activities }\end{array}$ & 39,7 & 10 \\
\hline State & & \\
\hline $\begin{array}{l}\text { Acquision and maintenance of buldings for US } \\
\text { government purposes }\end{array}$ & 140 & 2.8 \\
\hline Treasury & & \\
\hline Payments of 45 oblgations & 2.493.6. & 600 \\
\hline Sales tor dollars to US citzens, ete & 4566 & 14 \\
\hline Tansportation & & \\
\hline Scientific activities & 07 & 0.0 \\
\hline TOA & $\$ 41026$ & $100.0 \%$ \\
\hline
\end{tabular}

SOURCE US Department of Agrculture, food for Peace, 1979 Repon on Poblo LaW 480 , table 14.

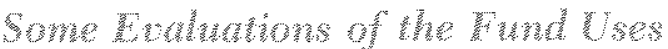

The real value of the payments (goods or services received to the United States for the food exports and the real cost of food (goods or services paid) to the importing nations has been the subject of an intense debate among economists for over two decades. The discussions largely have been centered around the balance-of-payments effects of the transactions, the value of the funds for economic development, and the value of the food to the recipient nations. 
Theodore Schultz, in a classic critique of the program in 1960, estimated that actual payments to the United States for shipments under this program would be between $10-15$ cents per dollar of CCC costs. ${ }^{7} \mathrm{~A}$ more optimistic view was presented by McGehee Spears and Dale Vining of the USDA Foreign Agricultural Service, who found the program a net generator of foreign exchange, noting: "Programs which generate needed foreign exchange without dollar purchase of such exchange, take on added, and positive, importance;" this implies that the currencies are valuable assets to the United States. ${ }^{8}$ Without making specific judgments about the value of the funds to the United States, Spears later concluded: (1) " . . foreign currencies acquired through the sale of surplus agricultural commodities are utilized advantageously in financing part of U.S. government military and economic assistance operations abroad;" and (2) the substitution by the United States of foreign currencies for dollar expenditures abroad prevented the overall balance-of-payments deficit from rising higher - that is, constituted real payments to the United States. ${ }^{9}$

A number of writers have pointed to the opportunities for using counterpart funds to finance economic development programs in the food importing nations. $S$. R. Sen, in reply to Schultz's criticism of the program, found that in India "the use that has been made of the counterpart funds in building up the infrastructure of the economy, in constructing irrigation and power facilities, improving transport and communications and promoting research and extension is certainly noteworthy. "10 R. O. Olson reported " ... the benefit (from use of the funds) depends on the extent to which the recipient country takes advantage of the presence of these goods [food shipments] to step up the pace of development. It can do this with created money...." In support of the program, Deena Khatkhate reported that the food shipments provided

\footnotetext{
"Theodore W. Schultz, "Value of U.S. Farm Surpluses to Underdeveloped Countries," Journal of Farm Economics (December 1960), pp. 1019-30.

${ }^{8}$ McGehee H. Spears and Dale K. Vining, Imporfance of U.S. Farm Exports to Balance of Payments, United States Department of Agriculture, Economic Reporting Service and Foreign Agricaltural Service, Foreign Agriculture Economic Report No. 7, October 1962.

McGehee H. Spears, "Recording P. L. 480 Transactions in the U.S. Balance of Payments," Southern Economic Journal (April 1963), pp. 340-45.

${ }^{10} \mathrm{~S}$. R. Sen, "Impact and Implications of Foreign Surplus Disposal on Underdeveloped Economies-The Indian Perspective," Journal of Farm Economics (December 1960), pp. 1031-42.

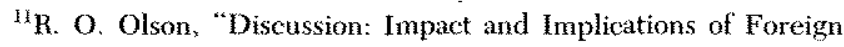

an important source of funds for investment in the public sector of India. ${ }^{12}$

Earl Heady and John Timmons in 1967, after pointing out the long-run impact of food aid on the population/food production ratio of P.L. 480 importing nations, reported individual elements of the program for example, some uses of counterpart funds - to be positive. They pointed to the program's impact in Israel as an example of the gains that can be achieved from the investment of such funds. Two methods were enumerated by which these funds assist capital investment: "First, funds which would go into food purchases abroad at unfavorable rates of exchange become available for investment within the country. Second, under Title I of Public Law 480, local currencies become available for internal developmental investment." 3

The debate on the value of the funds to the United States subsided somewhat with the phase-out of farm product exports for such currencies in the early 1970 s. Their use, however, continues to attract the attention of the daily press. ${ }^{14}$ Furthermore, in its annual report, Food for Peace, the USDA lists the uses made of the funds under a number of headings: export market development; market and utilization research; scientific, medical, cultural and educational activities; and build ings for the U.S. government. ${ }^{15}$

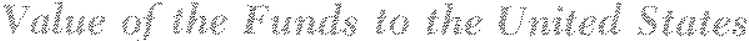

Some of the confusion about the value of the payments to the United States for the food can be eliminated by comparing the real value of the funds to the United States to the resources given up by foodimporting nations that receive the food. The value of the funds to the United States is approximately the real saving to the U.S. government resulting from their expenditure. The actual expenditure of the funds for U.S. uses is shown in table 2. The real saving to the

\footnotetext{
Surplus Disposal on Underdeveloped Economies," Journal of Farm Economics (December 1960), pp. 1042-45.

${ }^{12}$ Deena R. Khatkhate, "Some Notes on the Real Effects of Foreign Surplus Disposal in Underdeveloped Economies," Quarterly Journal of Economics (May 1962), pp. 186-96.

${ }^{13}$ Earl O. Heady and John F. Timmons, "Objectives, Achievements, and Hazards of the U.S. Food Aid and Agricultural Development Programs in Relation to Domestic Policy "Altematives for Balancing World Food Production and Needs (Iowa State University Press, 1967) pp. 186-214.

${ }^{14}$ Greenberger, "It May Surprise You."

${ }^{15}$ U.S. Department of Agriculture, Food for Peace, 1979
} 
United States resulting from their usage, however, is well below the indicated dollar expenditure figure. U.S. expenditures in the P.L. 480 food importing countries would have been much less had there been no foreign currency holdings; indeed, many of the expenditures would have never been made had outlays of dollars been necessary. ${ }^{16}$

A number of programs, such as trade fairs; agricultural market developments; health, education and welfare; cultural exchange activities; and Americansponsored schools, studies and conferences are associated closely with the P.L. 480 Act. As indicated in table 2, about one-third of the U.S. counterpart fund expenditures in all the participating nations through September 1979 was of this type. Without the funds, these programs would have been carried out on a greatly reduced scale, if indeed at all. Consequently, the real value to the United States of using foreign currency was well below the 26 percent of the total disbursed for U.S. uses. Since the counterpart funds credited to the United States covered only about 90 percent of the $\mathrm{CCC}$ outlays for the farm products exported, the actual recovery of CCC investment in the food was probably on the low side of the Schultz 10-15 percent estimate.

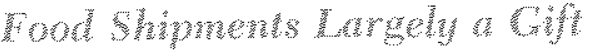

Since the food-importing nations reimbursed the United States for only about 10 percent of the original CCC investment in food, about 90 percent of the shipments were essentially a gift by the United States to the recipient nations. A gift of goods from one nation to another, however, is not neutral with respect to economic activity in either country. In this case, the policies that led to the gift caused increases in taxes, in the price of grain to producers, and in the price of food in the donor nation. The higher price of grain, in turn, provided incentive for farmers to purchase more resources and increase production, further increasing supplies in future years.

Moreover, the gift exacerbates the long-run food production problem in the recipient nations. "While consumers may pay less for food as the supply in-

\footnotetext{
"Greenberger, "It May Suprise You;" and Iimmye S. Hillman and Murray R. Benediet, "A Futther Look at P.L. 480 and the Balatice of Payments," Journal of Farm Economics (August 1966). pp. $728-37$

${ }^{17}$ The analysis here is intended to describe the effects of programs flesigned to reduce farm "surpluses." It does not necessarily describe the effects of humanitarian distributions of food and other atd intended to alleviate the short-run impacts of crop failures and other natural disasters.
}

creases, domestic farmers are subjected to further food price declines. The lower price reduces food production, thereby leading to less domestic food output in future years. Hence, these gifts contribute to further rural poverty in the recipient nations. ${ }^{18}$

The cost of the grain to the importing nations, although relatively small, has some impact on their balance-of-payments. It reduces their foreign exchange earnings to the extent that they would have received dollar exchange for the U.S. embassy expense, thereby reducing their ability to purchase other goods and services from abroad. Moreover, U.S. expenditures of funds that would not have been made in the absence of the accounts also are real costs to the importing countries. Resources used in these coun" tries by the United States for trade fairs, agricultural market developments, education, etc, are costs in terms of scarce goods and services. The use of these goods and services, while often looked upon as costless from the viewpoint of the U.S. users, are a real expense to the food importing nations. Hence, they will consider such expenses an important factor in negotiating P.L. 480 agreements and currency use projects.

Funds not used directly by the United States but credited to its account were disbursed for projects designed to benefit these less-developed nations. Funds, grants and loans were released for these purposes through agreements with their governments. Such grants and loans through 1980 totaled about $\$ 13$ billion or 75 percent of all foreign currencies credited to the United States in payment for Title I food shipments (table 1). This amount, plus the excess of CCC outlays for the shipments not credited to the United States, plus a portion of the U.S. uses of the funds represents the cost of this program to U.S. taxpayers that is not reimbursed by foreign governments.

The approximate real values exchanged in the P.L. 480, Title I, transactions may be summarized as follows:

\begin{tabular}{|c|c|c|c|}
\hline \multirow{2}{*}{\multicolumn{2}{|c|}{$\begin{array}{l}\text { United States } \\
\text { Market value of grain }\end{array}$}} & \multicolumn{2}{|c|}{ Recipient nations } \\
\hline & & & \\
\hline shipped & $100 \%$ & received & $100 \%$ \\
\hline Value of payment & & Cost of grain & $26 \%$ \\
\hline Tet loss to & $00 / 0$ & $\begin{array}{l}\text { Net gam to } \\
\text { recipients }\end{array}$ & $74 \%$ \\
\hline United States & $90 \%$ & & \\
\hline
\end{tabular}

The value of the grain to the United States and the receiving nations is assumed to be 100 percent of the

\footnotetext{
${ }^{18}$ For further discussion, see Dale W. Adams and Donald W. Larson, "What Cheap Food Does to Poor Countries," The Wall Street Journal, November 19, 1982.
} 
world market value for grain. Because the real value of the payment received by the United States is about 10 percent of the value of the grain shipments, the net loss to the United States totaled approximately 90 percent of the market value of the exports. The real cost of the grain to the recipient nations, however, totaled about 26 percent of the value of the shipments, and the net gain (value of the gift) to the recipients totaled 74 percent of the market value of the grain. The transactions resulted in a "welfare loss" of about 16 percent of the combined value of the shipments; in other words, real payments to the United States were about 16 percent of the market value of the grain below the real costs to the recipients. A case study of the portion of the P. L. 480 program that generated the funds in India indicates the real economic impacts of the transactions.

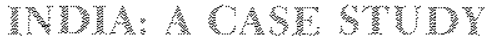

For two reasons, India is used to demonstrate the real impact of the P.L, 480 transactions that generated the counterpart funds. First, India has signed more agreements for Title I, P.L. 480 shipments than any other nation $-\$ 6.1$ billion, or about 40 percent of the total at the close of 1980 . Second, atthough there is a paucity of data for all the recipient nations, more data are available for India that for other nations.

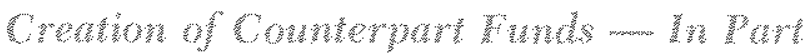

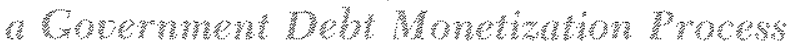

As indicated in figure 1, the government of India obtaned funds for P. L. 480 shipments by selling secuities to the Reserve Bank of India. ${ }^{19}$ Proceeds from the security sales were then credited by the bank to the Indian government (stage A, figure 1). Upon arrival of the food shipments, the funds were credited to the U.S. Treasury (stage B). These accounts were left on deposit with the reserve bank until disbursements were made in the form of loans and grants to India or for other uses as previously outlined. As the funds were disbursed, ownership was transferred to the private sector, and they eventually were credited to member bank accounts at the reserve bank, thereby increasing commercial bank reserves and the stock of money (stage C). If the process stopped at this point, all counterpart funds would be monetized following disbursement. The Indian government, however, recovered part of the finds from the public through grain sales at

\footnotetext{
19 Deena R. Khatkhate, "Money Supply Impact of National Currency Counterpart of Foreign Aid: An Indian Case," The Retiew of Economics and Statistics (a) ebruary 1963), pp. 78-83.
}

less than cost , partially offsetting the rise in bank reserves. Consequently, only the subsidized portion of the sales remained on the central bank's books.

Reserves for monetary expansion, thus, were increased only to the extent of the subsidy. Becanse the entire cost of $P, L_{1}, 480$ food imports was financed initially by government borrowings from the reserve bank, the excess of costs over proceeds from food sales remained in the banking system as an addition to reserves at the central bank after the counterpart funds has been disbursed (stage $\mathrm{E}$, last entry). With an estimated 50 percent of counterpart funds resulting from the central bank's financing of government deficits, the impact of such expenditures on bank reserves (highpowered money) was quite large. For example, by 1980, agreements had been made for the use of more than $\$ 4$ billion in counterpart funds in India ${ }^{20}$ On the basis of the estimated rate of subsidy on the food sales, this added more than $\$ 2$ billion (rupee equivalent) to bank reserves.

India has a relatively high ratio of currency to deposit money and the impact of increased reserves on the stock of money (currency plus demand deposits) in recent years has been relatively low - about one to one. Nevertheless, the addition of an estimated $\$ 200$ million in reserves in 1967 as a result of P.L. 480 operations caused a rise of about 3 percent in the money stock, which was about one-third the average rate of annual money growth from 1965 to 1970 . On this basis, the expenditure of counterpart funds accounted for about one-third of the 6.4 percent rate of inflation during the half decade. The addition of $\$ 2$ billion over a 25 -year period, thus, was a sizable factor contributing to the rise in the money stock and the relatively high intation rate. ${ }^{21}$

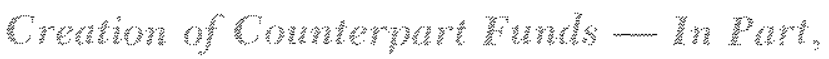

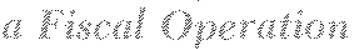

Partial recovery of the funds occurred when the government sold the imported food to the public and

\footnotetext{
${ }^{20}$ U.S. Department of Agriculture, Food for Peace, 1980 , takle 13.

${ }^{21}$ During the three years from 1964-65 to 1966-67, inclusive, the net Reserve Bank of Endia credit to the government and private sectors rose Rs. 1,401 crores, while the stock of money rose Rs. 1,201 crores

Typical of less-developed nations, currency in India is a more desirable fom of money than demand deposits. When curency is withdrawn from the banking system, it reduces bank reserves at a one-to-one ratio. In contrast, in the absence of large currency withdrawals, demand deposits can be expanded at some multiple of new reserves, depending on legal reserve requirements.
} 


\section{Figure 1}

\section{How Counterpart Funds Increase the Stock of Money in India (amounts in millions of dollars)}

\section{Stage A}

Government sells bonds to central bank to obtain $\$ 500$ millon to pay United States for grain

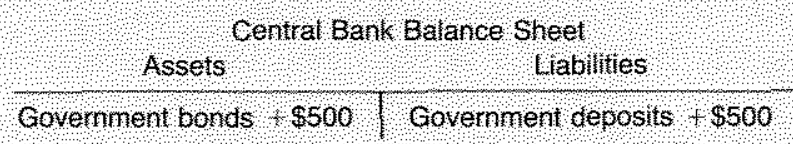

\section{Stage B}

Govermment pays United States for gram

L
Assets

\section{Stage C}

United States spends deposis in Indla for development purposes.

\begin{tabular}{rlll}
\hline & Assets \\
\hline
\end{tabular}

\begin{tabular}{|c|c|}
\hline \multicolumn{2}{|c|}{ Connerclal Bank Balance Sheel } \\
\hline Assets & 3 LLabilites \\
\hline Legal reserves $+\$ 500$ & Demand deposits 18500 (noney) \\
\hline
\end{tabular}

\section{Stage $D$}

Government sells grain to public at 50 percent of cost and reduces debt to central bank with ploceeds:

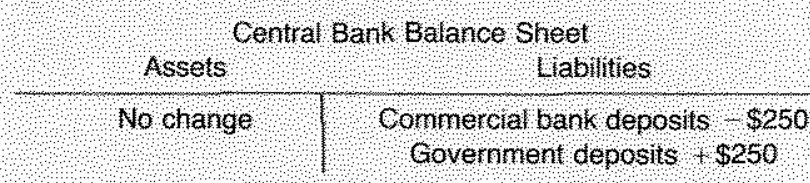

\begin{tabular}{|c|c|}
\hline \multicolumn{2}{|c|}{ Conmerclal Bank Balance sheet } \\
\hline Assets & Labilties \\
\hline Legal eserves $\$ 250$ & Demand deposits $\$ 250$ \\
\hline
\end{tabular}

\section{Stage $\mathrm{E}$}

Government reduces bonded debt to central bank

\begin{tabular}{|c|c|}
\hline \multicolumn{2}{|c|}{ Central Bank Balance Shed } \\
\hline Assets & 13 Labilities \\
\hline Governmentbonds $\$ 250$ & Government deposits $\$ 250$ \\
\hline \multicolumn{2}{|c|}{ Central Bank (FINAL) Bafance Sheet } \\
\hline Assets & Labilities: \\
\hline
\end{tabular}

Govenment bonds $+\$ 250$ Commercial bank deposits $+\$ 250$ paid off a portion of its debt to the reserve bank (stages $\mathrm{D}$ and $\mathrm{E}$, figure $\mathrm{I}$ ). If the deposits were made simultaneously with the disbursements and if the deposits were equal to the disbursements, the funds would have had no impact on the stock of noney. The proceeds from sales of P. L. 480 food to the Indian public, however, did not equal the rapee credits to the United States. The extent of the shortage is not available, but rough estimates indicate that no more than 50 percent of P.L. 480 wheat cost was recovered in some years (stage E). ${ }^{20}$ For example, the Reserve Bank of India reported that the issue price of imported wheat was raised from 50 to 55 rupees per quintal on November $15,1966, "$. . in accordance with the decision taken

\footnotetext{
${ }^{22}$ This estimate is based on the issue price of $40 \mathrm{Rs}$. per quintal (about $\$ 1 . \$ 0$ per bushel) and $\$ 1.73$ per bushel average cost at American ports. Ocean freight is estimated at $\$ 0.45$ per bushel and shipping and distribution cost in India at $\$ 0.40$ per bushel The zrevaling exhange rate of 13.3 cents per rupee was used in the calculations
}

by the Government to reduce gradually the element of subsidy. . . ."23

The portion of counterpart finds that was offset by sales of food to the public (funds available for reduction of government debt to the Reserve Bank of India) had no impact on the level of bank reserves or the stock of money. This portion was essentially a fiscal operation. Food, largely donated by the United States to the Indian government, was used as a means of transferring resontes from the private to the public sector. As indicated by Gary Seevers, proceeds from these sales may be viewed as an indirect tax on Indian farmers and a subsidy to consumers, because the producing sector suffered from lower prices and the consumer sector benefited from lower cost food. ${ }^{2+}$

\footnotetext{
${ }^{2}$ Reserve Bank of India, Report on Currency and Finance for the Year 1966-67, Bombay, 1967.

${ }^{2}$ Gary L. Seevers, "An Evaluation of the Disincentive Effect Caused by P.L. 480 Shipments," American Journal of Agricultural Economics (August 1968), pp. 630-42.
} 


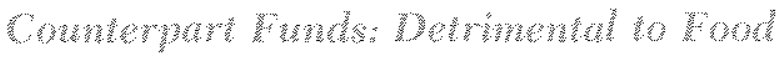

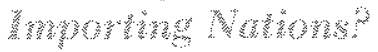

Whether counterpart funds contribute to economic development in the food recipient nations as alleged is not a crucial question concerning the creation and use of the funds. Similar investments readily can be made without the creation of counterpart funds. The fund expenditures did not add to the nation's stock of resources. For example, if all counterpart fund accounts were erased from the books of the Reserve Bank of India and the U.S. Treasury, the purchases for which the funds are used could be made by the Indian govermment through either the monetization of government debt, the levying of taxes or both. These actions could achieve the same results at no additional social cost.

Since rupee expenditures for development purposes or U.S. Department of Labor conferences could as readily be made without the counterpart fund accounts, the fund-creating feature of the program is not a requisite. Consequently, the creation and spending of counterpart funds does not appear to be a prow ductive function. Such funds (new money or taxes) could have been raised as readily without the currency credits to the United States. Benefits from U.S. participation in the programs would occur only if U.S, participants possess superior knowledge about development techniques and of the special conditions involved, neither of which is likely. Moreover, as indicated earlier, many expenditures would not have been made in the absence of counterpart funds, another indication of their wasteful use.

Counterpart fund accounts appear to represent idle resources abroad which, if not spent, would be wasted. Yet, their expenditure represents the utilization of real resources in the issuing nations. Further, it appears that the value obtained from their use to the United States frequently is less than the value of their use foregone by the other countries involved.

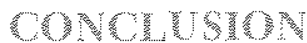

This article examines the results of crediting foreign currencies to the United States in payment for P.L. 480 food shipments abroad. The greater portion of the food shipments that led to the creation of these accounts was a gift of consumer goods by the United States to these nations.
The shipments provided additional net food resources to the recipient countries and made some contribution to their welfare in the short run. In the longer run, however, such gifts have an unfavorable impact on food production in the recipient nations. They affect producers in the United States and in the food recipient nations in opposite directions. Here, the government purchases cause an increase in the price of grain to producers and the price of food to consumers. U.S. farmers are provided incentive to further increase production. In contrast, the gift leads to lower prices for farmers in the recipient nations and reduces their incentive to produce. As a result, the recipient nations become even more dependent on the donor nations.

The use of counterpart funds in the program was predicated in part, on the belief that foreign currency credits are a vital factor in economic development in the food-importing nations; this belief is an illusion. The counterpart fund accounts currently on the central bank books represent one way of initiating money creation; however, governments always can create or destroy money at their convenience. The use of counterpart funds leads to an increase in the stock of money in these nations, not to an increase in resources or production. Because the quantity and use of real resources are important for development, resource use is likely to be more efficiently achieved under a simpler accounting system.

One solution would be simply to write off counterpart funds entirely and charge the expenditure instead to foreign aid. With the exception of the small amount of expenditure for embassy expense, etc, the funds are not payments to the United States and have no impact on the balance of payments. Both U.S. expenses and money creation in the LDCs would be under better control by writing off such accounts and negotiating the proportion of U.S. expenses offset by food shipments.

The importance of assessing the impact of counterpart funds in the context of the current problem of rising food surpluses is that it provides a reminder that even ostensibly charitable actions have hidden and unexpected impacts. Moreover, these unforeseen consequences often are detrimental to the presumed purposes of the program. The use of counterpart funds in the context of reducing the U.S. food surplus by shipping food to LDCs is such an example. 